\title{
Climate Change and China as a Global Emerging Regulatory Sea Power in the Arctic Ocean: Is China a Threat for Arctic Ocean Security?
}

\author{
Sandra Cassotta ${ }^{*}$, Kamrul Hossain ${ }^{2 \#, ~ M i c h a e l ~ E v a n ~ G o o d s i t e ~}{ }^{3^{\dagger}}$ \\ ${ }^{1}$ Department of Law, Aarhus University, (AU) Business and Social Sciences, AU/Herning, Denmark \\ ${ }^{2}$ Arctic Centre, University of Lapland, Rovaniemi, Finland \\ ${ }^{3}$ Institute of Technology and Innovation, University of Southern Denmark, Odense, Denmark \\ Email: SACP@law.au.dk, Kamrul.hossain@ulapland.fi, jire@iti.sdu.dk, migo@iti.sdu.dk
}

Received 23 July 2015; accepted 26 September 2015; published 29 September 2015

Copyright $(\underset{2015}{ }$ by authors and Scientific Research Publishing Inc.

This work is licensed under the Creative Commons Attribution International License (CC BY). http://creativecommons.org/licenses/by/4.0/

cC) (7) Open Access

\section{Abstract}

The impact of climate change in the Arctic Ocean such as ice melting and ice retreat facilitates natural resources extraction. Arctic fossil fuel becomes the drivers of geopolitical changes in the Arctic Ocean. Climate change facilitates natural resource extractions and increases competition between states and can result in tensions, even military ones. This article investigates through a political and legal analysis the role of China as an emerging regulatory sea power in the Arctic Ocean given its assertive "energy hungry country behaviour" in the Arctic Ocean. The United Nations Convention on the Law of the Sea (UNCLOS) and the Arctic Council (AC) are taken into consideration under climate change effects, to assess how global legal frameworks and institutions can deal with China's strategy in the Arctic Ocean. China's is moving away from its role as "humble power" to one of "informal imperialistic" resulting in substantial impact on the Arctic and Antartic dynamism. Due to ice-melting, an easy access to natural resources, China's Arctic strategy in the Arctic Ocean has reinforced its military martitime strategy and has profoundly changed its maritime military doctrine shifting from regional to global in the context of UNCLOS. In particular, it is wondered, what China understands about the public order dimension of UNCLOS. The article concludes that despite China' assertive behaviour towards the Arctic environmental ocean and its rise

\footnotetext{
"Sandra Cassotta is Assistant Professor in International Environmental Law at Aarhus University, and Jingzheng Ren is Postdoc at the University of Odense. They are both research fellows at the Institute for Security and Development Policy (ISDP) in Stockholm (Sweden) working under the Sino-Arctic Research Programme (SNAPP).

"Research Director (acting), at the Northern Institute for Environmental and Minority Law (NIEM), Arctic Center.

${ }^{\dagger}$ Head of Institute of Technology and Innovation, Senior Researcher at the Institute for Security and Development Policy (ISDP) in Stockholm (Sweden) and Leader of the Sino-Arctic Research Programme (SNAPP) at the ISDP.
} 
as global sea power, for the time being, China cannot be considered as a variable for Arctic security as there are no sufficient legal and policy objective elements to adduct that it constitutes a threat to Artic ocean security.

\author{
Keywords \\ Climate Change, China Foreign Policy, China's Arctic Strategy, United Nations Convention on the \\ Law of the Sea (UNCLOS), China's Maritime Strategy, China's Military Maritime Docrine
}

\title{
1. Introduction
}

While the United Nations (UN) Climate Secretariat of the United Nation Framework Convention on Climate Change (UNFCCC) based in Bonn is working hard to prepare for the Paris Meeting of the $21^{\text {st }}$ session of the Conference of the Parties to the UNFCCC which is expected to take place in December 2015, the Arctic is continuing to melt due to climate change effects. Climate change determines the retreat of ice in the Arctic Ocean. This is happening in a dramatic way from the period 1979 until 2012, ice coverage decreased by $50 \%$ (The National Snow and Ice Data Center index). This has created a huge access to petroleum, attracting strong interest by some states, especially energy hungry-countries, and increasing competition between states, resulting in tension and threats, even military ones (Contestaline, 2013).

From an Arctic Ocean security perspective, this imply that global legal frameworks such as the United Nations Convention on the Law of the Sea (UNCLOS) (Vidas, 2000) and institutions such as the Arctic Council $(\mathrm{AC})^{1}$ should be able to deal with climate change's uncertainties and potential threats, associated with specific Arctic and non-Arctic assertive "energy countries' behaviours" in getting easy access and control on oil and gas. China shows a voracious appetite towards petroleum and strong interest to get access to new navigable sea routes in the Arctic Ocean. In particular, China is moving away from its role as humble power" to one of "informal imperialistic" resulting in substantial impact on the Arctic dynamic and assert effective control over what happens in the Arctic.

Due to ice-melting and easy access to natural resources, China's Arctic strategy in the Arctic Ocean has reinforced its military maritime strategy and has profoundly changed its maritime military doctrine shifting from regional to global, in the context of UNCLOS. In particular, it is wondered what China understands about the public order dimension of UNCLOS in the Arctic Environmental Ocean activities. The expressions "Arctic Environmental Ocean" or "Arctic Ocean" are used indistinctly in this article to express the same concept because both connected to security and both assessing and including the risk and opportunities by the effect of climate change. The question of research of this article asks what is the nature of China's growing focus in the Arctic Environmental Ocean for Arctic environmental security, given its growing interest in Arctic environmental ocean law and politics and whether this focus should be objectively perceived as potential threat for Arctic Ocean security.

Under UNCLOS, both Arctic and non-Artic states have the right to engage in a range of activities in parts of the Arctic basin, including commerce, fishing and industrial shipping. ${ }^{2}$ This obliges states to respond individually or jointly to possible challenges, such as those which currently exist and which are involving Arctic states only. In particular, there are four potential conflicts of existing "tinderboxes" or "sleeping cells" in the Arctic Environmental Ocean, currently that could escalate "suddenly" and unexpectedly given the strategies of energyhungry countries, such as China. First is the US-Canadian dispute over the maritime boundary in the Beaufort Sea; the US also rejects Canada's claim to the Northwest Passage. Second is Russia's claim to the Lomonosov Ridge, which is contested by Denmark and Canada, which have been working together to find evidence of a

\footnotetext{
${ }^{1}$ The Arctic Council (AC) is a central multilateral instrument of scientific cooperation in the Arctic region and of crucial importance for the Arctic Environmental Ocean. The AC is characterized by its soft law, and flexible and intergovernmental nature. It was formed originally in 1991 to deal with disputes between Arctic governments and the environmental impacts that indigenous people might experience. It is compose by permanent members and observers. The permanent members are the US, Canada, Finland, Iceland, Russia, Denmark, Norway and Sweden. Recently, some non-Arctic states have applied for the status of observers, such as the EU and some Asian countries, such as China and South-Korea.

${ }^{2}$ The five Arctic states are the coastal: Norway, Denmark, Canada, US and Russia. The three Arctic non-coastal states are: Sweden, Finland and Iceland which all together are defined the "eight Arctic States".
} 
connection between the Greenland-Canada continental shelf and the Lomonosov Ridge. Third is Norway's claim to their position vis-à-vis Svalbard (the two-hundred-nautical-mile "fishery protection zone" declared around the archipelago). This is not accepted by Russia and many other states including Norway's allies, such as Iceland. Fourth is the Canadian-Danish disagreement over the tiny Hans Island ${ }^{3}$ which is more a dispute about the island itself, rather than one of the control of waters, navigation or seabed.

The potential conflicts are also kept under control by the AC even though there is not much that this institution can do from a security point of view, since it is mainly a scientific institute which aim to achieve scientific cooperation enacting soft law which does not deal with military and security issues. Equally important are the incentives of some Arctic states to enter into cooperative agreements with non-Arctic States regarding exploitation of natural resources.

In this regard, China's attitude towards Arctic is ambiguous. In this article, it is mooted first whether China's military strategy has profoundly changed and secondly, whether its maritime military doctrine has shifted from regional to global in the context of UNCLOS and thirdly, how this shift does applies to the Arctic Environmental Ocean basin in the growing interest in Arctic issues on the part of China. In particular, it is wondered what does China's understands about the public international order dimension of UNCLOS and how this reflects in the Arctic Environmental Ocean.

The article concludes that despite China' assertive behaviour towards the Arctic Environmental Ocean and its rise as global sea power, and its activities as a revisionist including new islands in the South China Sea, China cannot be considered to jeopardize Arctic security as there are no sufficient legal and policy objective elements to adduct that it constitutes a threat.

\section{Climate Change and China's Arctic Strategy as Variable of Arctic Environmental Ocean Security}

From scientific academic and non-academic analyses and mass-media news, China is on the spot because of its economic impressive growth. China has now all it needs to become a super-power nation. The price to pay for this is that its foreign policy is often taken under scrutiny sometimes with a strong vein of sensationalism. It has become trendy to continuously evaluate China's foreign policy especially the military aspect at the expenses of a certain American decline. Within the context of this international toile-de-fond, ice is melting in the Arctic attracting China's voracious appetite for natural resources and the possibility for navigating new routes and sea lanes significant for trade.

Time is particularly propitious now for China, which has become, in the meantime, a sea power nation (Xiaoyan, 2014; Holmes \& Toshi, 2007) having a strong command of all seas though new sophisticated strong technologies perhaps even able to challenge larger and more powerful navies, such as the American one, ${ }^{4}$ if capable also to fill the gaps of its weaknesses (Chase, 2015).

China has become a power nation by projecting its "power-strategy," (Chen, 2010), by starting to show a low and humble profile at the global level, challenging American military maritime supremacy. In the Arctic, China is not a new member of the AC and does not have a strong representative role (no voting rights) but wants to avoid being seen as a menace and thus isolated. ${ }^{5}$ China's foreign policy in the Arctic, especially the maritime military doctrine, is very ambiguous and heretic (Jakobson, 2014). However, there is an "order" in this ambiguous "disorder": a kind of doubly calculated diplomatic face-strategy. On the one hand, China shows only plans of science, partnerships, investments and a peaceful climate change adherence to the United Nations Framework Convention on Climate Change (UNFCCC, 1992) and Kyoto Protocol (Kyoto Protocol, 1997) showing a kind of

\footnotetext{
${ }^{3}$ The Hans Island is located in the centre of the Kennedy Channel of the Nares Strait, which separates Ellesmere Island from the Northern Greenland and connects the Baffin Bay with the Lincoln Sea.

${ }^{4}$ Among the existing different asymmetric approaches of the Chinese military maritime strategies and the superiority of their electromagnetic apparatus of combat, there is a possibility for China to attack the American naval command and information systems with possible defeat of the US. Pillsbury M., China Debates the Future Security Environment, National Defence University Press, at 293-95, (2000). In addition, the superiority of the China's navy has even been admitted by the US: at the end of the 98's, a report from the Pentagon denounced the strong modernization of the Chinese navy as a strong threaten for the US strategic interests in Asia, and on march 1999, the Congress enacted a huge document explaining how the improvement of the Chinese's military technologies had to be attributed to the intense spying activity conducted by Chinese scientists and students hosted in the US for research activities which determined also waves of discrimination and racism in the American scientific academic milieu against Chinese. See for that point Pichel (2002).

${ }^{5}$ In that sense, given that the US has the right to vote at the AC, China's want to avoid a replication of the Monroe's doctrine form which the US succeeded to completely isolated China in the past.
} 
environmental climate change diplomacy (Hongyuan, 2008) based on an image of peace (Tinanbao, 2007). On the other hand, the turn toward sea power (Bickford, 2011) makes China's an assertive behavior towards actions at sea and air space, emphasizing positions on sovereignty issues on actor's authorities at the AC, shows, a clear intention to re-interpret and re-design, the conceptual international public order of UNCLOS.

Hence, China's maritime military doctrine ${ }^{6}$ has to be understood as just a "component" of what is known as China's grand strategy (Goldstein, 2005) and is the key to understanding China's hidden ambiguous Arctic strategy.

It is very important to note, here, that we need to go into internal Chinese strategy of the sectorial maritime military doctrine first, in order to understand after, China's Arctic strategy, and that Chinese Arctic strategy is in turn just a component of its foreign policy, ${ }^{7}$ which is in turn a component of Chinese's global strategy.

China's grand strategy is thus a three-dimensional one that includes the Arctic as a part of its strategy and thus, a tool of power (since we said that in China, strategy = power).

But in all this discourse, one wonders what and where the connection between China's grand strategy and climate change in the Arctic is exactly. It turns out they are interconnected because the melting of ice permits natural resources to be extracted and shortens crucial navigation routes, both of which are key components of the China's foreign policy. The zones where natural resources lie and the navigation routes might become the theatre of a battlefield of threats and conflicts that will demand new maritime tactics. Most importantly, an effort to tackle the risk of climate change in the fields will be galvanized by the presence of unpredictable and assertive behaviors of ambiguous maritime military strategies, such as the case of China, a situation susceptible to becoming out of control as opposed to the same situation occurring in the absence of climate change effects.

In order to clearly figure out China's foreign policy intensions to grasp the extent to which it pursues its foreign policy and to observe if China is a threat or not for the Arctic, two possible views have been applied: 1) China as "status quo," thus viewing it as non-threatening, or 2) China's as "revisionist" thus viewing it as a threat (Rainwater, 2013). As is will be analysed more in detail in section 2.3 of this article, in the "status quo" view, states tend to design the rules of the game and maintain balance of power and tend to international cooperation. In a "revisionist" approach, states are not satisfied with the rules and decide to change them. Thus, this section will shed light on China's power to vary Arctic Ocean security by analyzing a specific aspect of a change that occurred in its foreign policy: the change in its maritime military doctrine as a key component of its Arctic strategy (Section 2.1) and observe from there how China perceives its adherence to UNCLOS as part of its grand strategy (Subsection 2.2). This will serve to finally elucidate if China represents a threat or not to Arctic Environmental Ocean security (Section 2.3) in the context of climate change effects and energy resources needs.

\subsection{China’s Emerging Arctic Strategy as Component of Its Maritime Military Doctrine}

It is not easy to use scientific inquiry to see if China's foreign policy has changes. Furthermore, even if one succeeds in proving that there has been a change, it is not easy to define it. In order to fully grasp this change, it is fundamental to identify the "constant" while analyzing a specific change or the carpe diem momentum. The difficulty consists in succeeding to "photograph" within the lapse of time/space field, what has exactly changed, and to catch it.

In China's foreign and security policy, our "constant field" is China's "grand strategy," which has not changed. But what has changed, is the way through which the political objectives of this grand strategy work, because now they are interconnected with military instruments. In other words, what has changed here is "Chinese military maritime doctrine". This is a first significant element of enquiry unveiling a change visible in the Chinese military strategy from 2007 onwards, especially under the President Hu Jintao administration period (Fang \& Wang, 2007). Hu Jintao created and launched a new view of using military strategy to put forward a new form of control of maritime space including struggle preparations and instill the idea that China had to be prepared for struggle not only “internally” or in China’s neighbor's internal seas, (jinhai zonghe zuozhan: 近海 综合作战) (Fang \& Wang, 2007) but also “externally” or in China's distant or “open seas” (yuanhai jidong zuozhan: 远海机动作战) (Fang \& Wang, 2007).

In international relation (IR), at a general level, the concept of "grand strategy" is used to define the highest level of the foreign and security policy formation of a given state, which is normally a "general" and "abstract"

\footnotetext{
${ }^{6}$ The meaning of the term "doctrine”, here, in the military jargon, will be elucidated in the next section.

${ }^{7}$ The "foreign policy”, here, is the China’s foreign policy.
} 
strategy, defining long-term objectives in international affairs through the use of precise instruments (Posen, 1984). A grand strategy represents an element of continuity and generally does not change, but what changes is the way through which its political objectives are achieved, for example, if they are strictly connected to military instruments. Thus, here lies the heart of the difference between "grand strategy" and "military doctrine". Barry Posen also distinguishes "grand strategy" from "military doctrine". He defines the military doctrine as a "sub-component of the grand strategy that concerns what military means shall be emphasizes" (Posen, 1984). It is a struggle between "the good and the bad" fighting on a battlefield where distinct political and military interests meet and struggle to gain policy control and then exercise power. In that sense, since military doctrine uses military instruments to achieve political objectives, it is a system of common credo and values of a state, and therefore of fundamental importance to analyze changes of strategies. But what are the grand strategy, and the military maritime doctrine, in the case of China? And most importantly, what are the military grand strategy and military maritime doctrine of China in the case of the Arctic Ocean?

China's grand strategy is attempting in the long-term to transform the current unipolar system in which the US is the sole superpower into a multipolar system (Bickford, 2001; Goldenstein, 2005). In that sense, Deng Xiaoping's statement insisting on the importance of China showing a low-profile attitude is significant. This attitude consists of "hiding its capabilities and binding its time when it was relatively weak from weakness to strength it will pursue the strategic goal of regional preponderance and re-establishment of a Sino-centric world system" (Friedberg, 2011). Also, for sovereign China, there are some interests that are vital due to its past: the "territory" and the "political integrity" and the protection of its territorial sovereignty. These cannot be understood without delving into China's history and the deep rooted psychosocial mechanisms of self-protection of this marvelous, ancient and extremely culturally rich country that had to accept terrible dominance and humiliations from attack because of imperialistic jealousy.

The two examples are China's protection of its interest in the South China Sea, and the issue of Taiwan. Here China is protecting its core territorial interests, creating international tensions for years because of oil, gas, and fishing disputes on the use of the seabed.

An important question is what China's projection of its grand strategy is for the Arctic. Even though China is the only non-Arctic country that does not have an "official Arctic strategy," the country is actually following a logic of "non-strategy" based on a precise, salient calculated axiomatic Arctic strategy. This strategy is based on three axioms which are extrapolated from the above "mother" matrix general grand strategy and projected in the Arctic zone: i) avoiding confrontation; ii) building comprehensive national power, and iii) advancing incrementally, a low-profile and "double face strategy," not visible but existing nonetheless (Friedberg, 2011; Chen, 2012).

It remains to be seen if this strategy matches and corresponds to what China is effectively operationalizing "in the Arctic field." In the next section, this strategy will be scrutinized from a legal point of view to detect or better "decrypt" China's interpretation of UNCLOS and its behavior within the national Exclusive Economic Zones (EEZs).

Military maritime Chinese doctrine in the Arctic is a very opaque component, despite of the release of the latest China's Defense White Paper in May 2015. ${ }^{8}$ It is clear that China's military maritime doctrine for the case of the Arctic Ocean, is not asymmetric because China's military doctrine and strategy coincides, since for China, power = strategy. China is, however, developing asymmetric capabilities that can strategically keep under control key Arctic sea areas or passages or lanes where military operations could be carried in the strategic right places calculating in advance key maritime spaces as "La maîtrise de l'espace sera condition préalable pour la victoire navale, l'espace devenant les nouvelles hauteurs de commandement pour le combat naval" (Chen, 2012). In a more concrete way, the key zones parts of this "asymmetric" China’s military maritime doctrine are the Malacca Straits and the sea lines of communications (SLOCs). The Malacca Straits, also known as the "Malacca Dilemma," is a shortcut, a crucial strategic sea passage via the Arctic Ocean, connecting the Indian Ocean, one of the world busiest sea passages, and the South China Sea, where 85 percent of the oil imports passes through (Chen, 2012).

The SLOCs are strategically important for trade and resource acquisitions, providing primary long-term access to resource, a primary objective of China's foreign policy and security.

The South China Sea is a key zone to both regional and non-regional countries including Canada. China's

\footnotetext{
${ }^{8}$ Report, National Maritime Foundation, “China Challenges the Unipolar World Order: An Assessment of China's Defence White Paper”,
} 2014", 03 June 2015. 
good diplomatic relations with some countries of the Indian Ocean are part of the key zones in connection with the Arctic, guaranteeing to the Chinese army, the necessary logistic support without the need to conclude formal military cooperative agreements. This is what the military American doctrine defines as "military places" as opposed to "military bases" which are not permanent military structures directly managed but rather flexible points for logistics purposes. Another passage relevant for trade is the Arctic shipping route in China, the leasing of North Korea's port of Rajin by Hunchun Chuangly Haiyn Logistic Ldt, based in the neighboring Jilin province in the northeast of China and Rijin lying on the far north eastern tip of North Korea, close to Russia (Jakobson, 2012), a very sensitive aspect for the Arctic Ocean environmental security.

In substance, China's Arctic strategy is visible and deductively understandable from its military maritime doctrine, its logic and consequence coupled with the legal reasoning behind China's interpretation and understanding of UNCLOS. This will be further developed in the next section; it is an important component of its maritime military doctrine, even if it is very difficult to find documentation to prove the change in this doctrine. The proof of the change will not to be found in non-Chinese literature nor in the black box of the Chinese decision-making process, nor using orthodox rational choice theories, because they are not suitable for this type of investigation and because most of the documentation is top secret.

\subsection{How Is China Interpreting the UNCLOS Convention?}

China's energy import economy and control of maritime areas is a strategy of "back shoulders" to remedy its weak role as an actor in the Arctic arena: China was denied status of permanent observer at the AC three times. In order to fully grasp China's position as non-Arctic actor, it is important to observe first how China understands UNCLOS and how the entrenchment between its domestic legislation with the interpretation of international public law of the sea is entangled. In other words, China is projecting its grand strategy to the global level as an "expansion" of its own internal grand strategy, and the way China legally interprets UNCLOS revails the prelude of its future Arctic strategy, understood just an area of its principle of projection.

There are two groups of legal issues relevant to understanding China's interpretation of UNCLOS and its position in the Arctic Ocean governance: one indirect and two direct.

The indirect group links to reservations under which China ratified UNCLOS, specifically: 1) China's position regarding the South China Seas, which means that China ratified the UNCLOS with the understanding that it does not impinge upon its sovereign claims to all the islands and regions of the South China Seas, 2) China's explicit renunciation of arbitration as a method for solving maritime dispute; ${ }^{9}$ and 3) China's denial of the right for the innocent passage of warships in its territorial seas prior to its authorization (Peng \& Wegge, 2014).

The direct group links to China's interpretation of the concept of "air space" in the Arctic and China understands of the concept of "common heritage."

Regarding the "air space" it is worth noticing that UNCLOS considers air at the same level as it considers water, which means the same line of public international law reasoning applies. In fact, if we observe the concept of "territorial sea" and the "delimitation of the territorial sea" under UNCLOS, the latter considers not only "water" but also the sea-bed, superjacent waters and the "air column". Therefore, air is also considered under UNCLOS.

What is doubtful here, is the Chinese concept of "air space" in the recent China's Declaration of an Air Defense Identification Zone (ADIZ) in November 2013 over the East China Sea (including the space claimed by Japan and Taiwan) (Jakobson, 2012). This lead to serious frictions with other states such as the US, and Japan which contends that China's ADIZ position is contrary to international public order of the law of the sea and contravenes Article 85 of UNCLOS (Lee, 2014). The question opens a huge question about how does China interpret silence in international law and the significance of the presumption of good faith.

As to the second legal issue, we have to reflect on the way China interprets the concept of "common heritage". UNCLOS uses to the notion of "common heritage" to refer to the "high seas" which are res commune and res nullius under the doctrine of "high seas," which means that they do not belong to anyone. Res communes and res nullius are thus the "high seas" that are designated under UNCLOS as the area that lies beyond the EEZ. China instead asserts its rights by using the same language in UNCLOS to argue that the Arctic and all its resource are

\footnotetext{
${ }^{9}$ China made an official Declaration after ratification of UNCLOS (25 August 2006) rejecting international arbitration for settlement of marine disputes. China's Declaration under Article 298 of UNCLOS Convention is stating "The Government of the People's Republic of China does not accept any of the procedures provided for in Section 2 of Part XV of the Convention with respect to all the categories of disputes referred to in paragraph 1 (a) (b) and (c) of Article 298 of the Convention".
} 
the "common heritage of all humankind" and in that way misinterprets this concept of "common heritage," including in its interpretation the notion that the "entire Arctic Ocean" is common heritage, a way to "expand" its grand strategy. Through this expansion, China justifies its legal rights to the Arctic Ocean (Rainwater, 2013). By misusing the law and the letter of the meaning of public international legal order of the sea, China is achieving one of its objectives, part of its grand strategy. Though its maritime military doctrine and asymmetric military techniques applied to the sea, China uses the law as a surrogate for traditional military means to achieve operational objectives.

\subsection{Is China a Threat or a Peaceful Variable to the Arctic Ocean Security?}

The attitude of China towards the Arctic and UNCLOS as applied to Arctic issues can also be decrypted using a spectrum approach of "status quo" or "revisionist" to assess the extent to which China has achieved its foreign policy objectives in the Arctic (Rainwater, 2013; Morgenthau, 1978; Schweller, 1994). Morgenthau and Scheller, two political scientists, defined "status quo states" as those that tend to design the rules of the game and maintain balance of power and tend to international cooperation. The "revisionist" approach is the one where a state is not satisfied with the rules and decides to change them. The revisionist approach tends to redraft the rules or breach them or disregard them tout-court with the precise purpose of "pivoting the power not balance" and redistributing power using its instrument per excellence: the role of the military. ${ }^{10}$ Usually, states with a revisionist approach tend to use the military force to change the status quo and instill new credo and values.

Morgenthau and Schweller's analytical, theoretical spectrum approach applied to the case of China's foreign policy and its maritime military doctrine, clearly illustrate at the surface that both indirect and direct legal issues salient to grasp China's interpretation of UNCLOS expressed in the previous section ${ }^{11}$ matches the pattern of "status quo" and "revisionist". To get a more complete vision of the puzzle, this "pattern-matching" would need to be integrated with the effects of climate change, in particular the risk of adaptation since possible assertive behaviors in term of conflict could not only galvanize one approach or the other ${ }^{12}$ and increase insecurity but also delay the adaptation of security as a full part of the adaptation process to climate change. ${ }^{13}$ Hence, both environmental and human risks, including possible conflicts, must be treated together in order to permit adaptationto take place as climate change and damages does overlap to natural disaster and conflicts, and frequency of extreme events. In adaptation, "variability" not "change" is the most problematic as highlighted in a research programme, taking precisely the Arctic as a case study (Revilla, 2010). Climate variability, not just to change of temperature is very difficult to predict and tackle because it requires far more information and resources than we have for detection, planning decision-making and successful implementation. In adaptation to climate change, variability is more challenging than changes themselves because the greater stress on humans and societies is caused by variability in access to natural resources, not by the level of access alone.

Adaptation is an extremely sensitive issue in the Arctic Environmental Ocean and has its peculiarities linked with eco-systemic, societal and security aspects of what can be defined a "marine and costal adaptation" as climate change means for the Arctic Environmental Ocean a rise of sea levels, melting ice, ocean acidification all shifting ranges of fish stock and damaging the ecosystem. Because of ice melts or retreats this has a consequence for the potential loss of maritime jurisdiction for coastal states and also for possible military conflicts regarding control over natural resources due to ice melts, which makes it easier to have access to natural resource and to drill or to extract minerals.

The transformation of the Arctic environmental Ocean due to environmental changes could change the field of international law. This can be observed, for example, on how states are adapting to the new situation by extending their jurisdiction on the basis of Article 76 of UNCLOS. Article 76 is the one treating the right of use of

\footnotetext{
${ }^{10}$ The role of the military, here to be understood as "power".

${ }^{11}$ In particular the legal issues exposed in the previous section are, first, the three indirect legal issues: i) China's position as to South China Seas, ii) China's derogation from arbitration as a method of dispute settlement on UNCLOS, iii) denial of the right of innocent passage of warship in its territorial seas prior authorization. After, the two direct legal issues directly reflecting in the Arctic Ocean governance 1) Chinese's public international concept of "air space" in the Arctic and 2) China's understanding of the concept of "common heritage".

${ }^{12}$ The "status quo" or the "revisionist” approaches.

${ }^{13}$ The concept of adaptation has to be understood in contrast to the concept of mitigation. The UNFCCC seeks to achieve the objective to reduce GHG by using two methods: mitigation and adaptation. Mitigation refers to human interventions to reduce GHG from sources, or to enhance their removal by sinks. By contrast, adaptation refers to adjustments in practices, process or structures which can moderate or offset the potential for damage or take advantage of opportunities created by a given change in climate. The two methods, mitigation and adaptation, are in contact by can be linked.
} 
continental shelves and is, thus, very important to obtain access to natural resources especially fossil fuel (oil and gas). The reason why this article is related to the extension of jurisdiction of state it is because states have the possibility to extend their jurisdiction if their submit a claim to the Commission on the Limits of Continental Shelfs (CLCs which is not a legal body but a technical body) to have more territory than what is permitted by UNCLOS and what is permitted is 200 Nautical Miles (NM) from the coast.

States can apply to have more territory but not more than $350 \mathrm{NM}$ in total. What happen beyond the $350 \mathrm{NM}$ thus is considered to be "high sea". Therefore it is uncertain and unpredictable what will happen after the 350 NM and the UNCLOS is very "grey" on that part and this gap represents a floating enigma potentially dangerous for the Arctic Environmental Ocean peace and security management.

In a more concrete way, China's position regarding the South China Sea, means employing naval military force to extend its borders in defiance of the 200 NM limits of UNCLOS, breaching the rules, providing evidence that China is challenging the maritime status. This constitutes a "revisionist" attitude to the disadvantage of the US (Blummental \& Mazza, 2012). With regard to China's denial to recognize arbitration this can be considered as a retreat from customary international law of the sea, instead endorsing peaceful dispute settlements. As to the denial of innocent passage, it is more than evident that we are dealing again with a "reformist approach" where China wants to reform a system because such a system is unsatisfying and, thus, wants to establish a new maritime behavior by exploiting a legal caveat of interpretation of UNCLOS, a gap where it is not totally certain as to what military activities are allowed in a country's EEZ. ${ }^{14}$

Normally the "doctrine of the high seas" expresses the freedom of high seas which includes the use of the sea for military exercises and maneuvers including the use of weapons. This freedom includes the freedom to operate in the EEZ under UNCLOS. Nevertheless, the formulation and the language in UNCLOS's provisions are vague, and it is not totally certain which kinds of activity are allowed.

Also with regards to the direct legal issues reflected in the Arctic Ocean governance, in particular the connection to reinterpreting "air space” (with the Chinese Declaration of ADIZ) ${ }^{15}$ and interpreting "common heritage", both are examples of an attempt to modify the law of the sea and with significant revisionist implications for the public international legal order with clear signal of willingness to reinterpret the law of the sea. In the substance, if a balance between the two tendencies, "status quo" and "revisionist," is traced, the "revisionist" is China's major attitude in Arctic Ocean governance. But it is important to note that UNCLOS has gaps, as outlined previously. Hence, objectively, on the one hand it can be deduced that China's foreign policy and security tend to have a revisionist assertive behavior which is ceteris paribus motivated by the intention to exploit the gaps of UNCLOS on its own benefits.

On the other hand, China also has a status quo behavior cooperating with a soft diplomacy in the scientific sector, or "scientific diplomacy" building up several partnerships with Arctic universities and peaceful cooperation, especially in science and technology research. For example, research institutions in China play a key diplomatic soft power role of balance, especially in strategic links between research institutions and individual academics in order to help policymakers to provide policy recommendations for peaceful cooperation in which science and technology represent a tool of intermediation, if is thought for example on the existence of the Polar Research Institute of China (PRIC) an institution responsible for polar expeditions, and the Shanghai Institute of International Studies (SIIS) operating in the area of international affairs.

\section{Conclusion}

In the middle between "status quo" and "revisionist", China as a variable in Arctic security is not a threat as such. The threats could come from the conditions under which China acts according to one tendency or the other, ${ }^{16}$ tendencies that become galvanized by the climate change risk's adaptation, especially taking into account the "variability" component. This is why it would be so important to design new legal frameworks that contain risk assessment that permits adaptation and prevents the problems that come with. Nevertheless, the absence of competence of the AC on security matter is problematic.

\footnotetext{
${ }^{14}$ Article 58 of UNCLOS states "All States, whether coastal or land-locked, enjoy, subject to the relevant provisions of this convention the freedoms... of navigation and overflight ... and other internationally lawful uses of the sea related to these freedoms, such as those associated with the operation of ships (and ) aircraft".

${ }^{15}$ See previous section of the present article.

16“"Status quo" or "revisionist".
} 
China's behavior is more revisionist than status quo, and could be a threat if this revisionist tendency is linked to an Arctic existing conflict or defined as "tinderboxes" in this article, and if China acts in conflagration with other Arctic actors especially under new conditions of "uncontrolled" effects of climate change, and if adaptation is impeded or delayed. This informative analytical aspect is necessary if we are to anticipate changes to the Arctic Ocean peace and security area and unsuccessful adaptation processes.

\section{References}

Bickford, T. J. (2011). Uncertain Waters: Thinking about China's Emergence as a Maritime Power. Report, CAN China Studies, CRM DOO25813.A1/Final, September, 1-80.

Blummental, M. D., \& Mazza, M. (2012). Why to Forget UNCLOS. The Diplomat, 17 February.

Chase, M. et al. (2015). China's Incomplete Military Transformation, Assessing the Weakness of the People's Liberation Army (PLA). Rand, National Security Research Division, 1-184.

Chen, Z. (2010). La stratégie militaire "asymétrique de la Chine-Logique et conséquences. Revue Etude internationales, $X L I, 547-569$.

Contestaline, M. (2013). Climate-Conflict Nexus. Nature Climate Change, 3, 15.

Fang, Y. G., Wang, M. S., \& Xu, S. M. (2007). On Creative Development in the Party's Guiding Theory of Naval Building. China's Military Science, 20, 66-77. (In Chinese).

Friedberg, A. (2011). A Contest for Supremacy: China, America, and the Struggle for Mastery in Asia. New York: WW. Norton.

Goldstein, L. J. (2005). Introduction. Chinese Perspectives on Maritime Transformation. In A. S. Erickson, \& J. Goldstein Lyle (Eds.), Lord Carnes, China Goes to Sea. Maritime Transformation in Comparative Historical Perspective (pp. xiii-xxxvi). Annapolis: Naval Institutes Press.

Holmes, J. R., \& Toshi, Y. (2007). Chinese Naval Strategy in the 21st Century. The Turn to Mahan. Abingdon: Routledge Erickson.

Hongyuan, Y. (2008). Global Warming and China’s Environmental Diplomacy (pp. 1-189). New York: Nova Science Publishers, Inc.

Jakobson, L. (2014). China's Unpredictable Maritime Security Actors. Lowy Institute for International Policy, 6.

Jakobson, L., \& Peng, J. (2012). China’s Arctic Aspirations (p. 8). Stockholm International Peace Research Institute (SIPRI), Policy Paper No. 34, SIPRI.

Kyoto Protocol to the United Nations Framework Convention on Climate Change, Kyoto, 10 December 1997.

Lee, J. (2014). China’s Declaration of an Air Defence Identification Zone in the East China Sea: Implication for Public International Law. ASIL, Insight, 18, Issue No. 17.

Morgenthau, H. J. (1978). Politics among Nations: The Struggle for Power and Peace (5th ed.). New York: Alfred A. Knopf.

Peng, J., \& Wegge, N. (2014). China and the Law of the Sea: Implications for Arctic Governance. The Polar Journal, 4, 294.

Pichel, C. E. R. (2002). La Cina. La Politica Estera di un Paese Sovrano, Franco Angeli Società e Politica, 101.

Posen, B. (1984). The Sources of Military Doctrine: France, Britain and Germany between the World Wars (p. 13). Ithaca, NY: Cornell University Press.

Rainwater, S. (2013). Race to the North, China’s Arctic Strategy and Its Implications. Naval War College Review, 66, 62-82.

Revilla, C. C. et al. (2010). Agent-Based Modelling of Climate Change, Ecosystem, and Security: A Research Programme. Proceedings of the 250th Anniversary Conference on Climate Change and Security, Trondheim, 21-24 June 2010, 4.

Schweller, R. L. (1994). Bandwagoning for Profit: Bringing the Revisionist State Back. International Security, $19,72-107$. http://dx.doi.org/10.2307/2539149

The National Snow and Ice Data Center Sea Ice Index, Climate Central.

Tinanbao, Q. (2007). Report, China’s Peaceful Development and Global Climate Change: A Legal Perspective. Law Environmental and Development Journal, 3, 56-69.

United Nation Convention on the Law of the Sea (UNCLOS), 1982.

United Nations Framework Convention on Climate Change (UNFCCC), 1992.

Xiaoyan, W. (2014). China's Sea Power Nation Strategy. Institute for Security and Development Policy, 1-26. 